\title{
Self-inflicted ventricular septal defect
}

\author{
D. G. Leaver , R. N. Sharma, and J. S. Glennie \\ From National Heart Hospital, London W.I, Royal Lancaster Infirmary, Lancaster, and \\ Victoria Hospital, Blackpool
}

A case of attempted suicide is described which is believed to be the first reported example of survival after a self-inflicted penetrating knife wound of the heart. The $12 \mathrm{~cm}$. blade entered the right ventricle and damaged one of the papillary muscles. The ventricular septum was also perforated. At cardiotomy the stab wound in the free wall of the right ventricle was surtured and the papillary muscle repaired. The ventricular septal defect was closed, but a small left-toright shunt at ventricular level reappeared after operation.

In an attempt to commit suicide a young man stabbed himself twice in the chest. The knife entered the right ventricle, severed a papillary muscle, and created a ventricular septal defect. Among previously recorded cases of knife wounds penetrating the heart, and treated successfully by operation, we have found none in which the injury was selfinflicted.

\section{History}

The patient, a 20-year-old university biology student, attempted suicide at 10.30 a.m. on 5 February 1968, inflicting razor wounds to his left wrist, and twice plunging a $12 \mathrm{~cm}$. knife (see Fig. I) into his left upper chest. He was not found until late afternoon and was taken to the local casualty department at 4.30 p.m., six hours after the injury. He was admitted to a surgical ward at the Royal Lancaster Infirmary where he was seen by one of us (R.N.S.) together with Dr. G. M. Barrett, Consultant Physician. The stab wounds were in the 4 th left intercostal space $3.5 \mathrm{~cm}$. from the mid-line. A systolic thrill was palpable over the anterior chest wall, and there was a loud pansystolic murmur maximal at the apex. He was mildly shocked with peripheral vasoconstriction, small volume pulses, sinus tachycardia of $120 /$ minute, and blood pressure of $1 \mathrm{ro} / 80 \mathrm{~mm}$. Hg. An electrocardiogram showed right bundle-branch block. From previous hospital admissions in 1965 (viral meningitis) and 1967 (infectious mononucleosis), it was known that the cardiac signs were new, and a diagnosis was made of traumatic ventricular septal defect, with probable damage to the right branch of the bundle of His. The patient

* Present address: Hammersmith Hospital, London W.r2. was transferred to the regional thoracic-surgical centre at Blackpool where on arrival the physical findings were unchanged.

On 6 February, an exploratory thoracotomy was performed (J.S.G.). The chest was opened through a mid-line sternotomy and the heart exposed. There was a single transverse wound in the pericardium $0.5 \mathrm{~cm}$. in length, and this overlay a similar wound in the anterior wall of the right ventricle. There was no blood in the pericardial cavity. After instituting cardiopulmonary bypass the right ventricle was opened through a transverse incision. The septal papillary muscle of the tricuspid valve was almost completely severed, and there was a $1.5 \mathrm{~cm}$. opening through the ventricular septum. The papillary muscle was repaired and the septal defect closed with 3 silk mattress sutures. During the first postoperative day a soft systolic murmur was heard which gradually increased in intensity, until by 9 March 1968, it was described as a loud pansystolic murmur localized at the left sternal edge. It was assumed that one or more of the stitches securing the ventricular septal defect had cut out. The patient's recovery, however, was uneventful except for a penicillin sensitivity reaction.

Nine months after operation he was referred to Dr. Richard Emanuel at the National Heart Hospital because the heart murmur made him unacceptable to many employers. On admission in January 1969 he was asymptomatic. The physical findings included the median sternotomy scar, scars of the two stab wounds (see Fig. 2), a localized systolic thrill in the $4^{\text {th }}$ intercostal space at the left sternal edge, and a corresponding loud pansystolic murmur. Chest radiograph was normal without cardiomegaly or pulmonary plethora. There was complete right bundlebranch block with a QRS duration of 0.16 sec. Cardiac catheterization (D.G.L.) showed a small 
left-to-right shunt at ventricular level with a pulmonary systemic flow ratio of $I \cdot 8: I$, and the left ventricular angiogram confirmed a ventricular septal defect in the middle third of the septum.

\section{Discussion}

We can find no recent reports of survival with a ventricular septal defect after a penetrating injury of the heart. Sir Charles Ballance (1920) in the Bradshaw Lecture of 1919, entitled 'The Surgery of the Heart', quoted a case reported by Mühlig (I86I) of a man who was stabbed in the chest with a knife and survived for Io years. After the injury a heart murmur was audible, and at necropsy a ventricular septal defect was found together with an aneurysm of the right ventricle at the site of the original wound. This has obvious similarities to our case. Ballance also mentioned a case of attempted suicide by stabbing, originally recorded by Larrey (1829). 'On February 28th, I824, a soldier on active service aged 22 stabbed himself under the 7 th rib ... there was considerable haematoma and haemopericardium causing the patient great distress'. Larrey evacuated the haemopericardium by enlarging the wound and inserting a catheter which reached the heart. The patient ultimately recovered and was presented at a meeting of the Surgical Academy in Paris on 15 April 1824.

One of the remarkable features of our case is the delay before medical treatment was sought and the apparent lack of symptoms; however, comparatively long survival without treatment has been recorded. Kearns (1935), quoting Piga's (1929) report of longterm survival after heart wounds, noted 82 cases of penetrating wounds of the right ventricle (Table).

\section{TABLE}

\begin{tabular}{|c|c|c|c|c|c|}
\hline $\begin{array}{l}\text { Survival } \\
\text { Patients }\end{array}$ & $\begin{array}{c}\text { I-6 } \\
\text { hours } \\
12\end{array}$ & $\begin{array}{c}7-24 \\
\text { hours } \\
9\end{array}$ & $\begin{array}{c}1-30 \\
\text { days } \\
7\end{array}$ & $\begin{array}{c}30 \text { days- } \\
\text { I year } \\
48\end{array}$ & $\begin{array}{c}\text { I year } \\
6\end{array}$ \\
\hline
\end{tabular}

Parmley, Mattingly, and Manion (1958) reviewed post-mortem statistics of 456 cases of penetrating wounds of the heart and aorta, and found that $2 \mathrm{I}$ per cent survived long enough to reach medical care; Ior were stab wounds and 55 of these died with haemopericardium. The role of haemopericardium in survival remains controversial. Maynard, Cordice, and Naclerio (1952) reviewed 20 cases of stab wounds penetrating the right ventricle: 19 of these developed tamponade and only one died. The remaining patient reached an operating theatre without tamponade but died from exsanguination before operation. Their report included two patients in whom decompression of the haemopericardium showed that the wound in the right ventricle was sealed by clot. These authors therefore suggested that haemopericardium was a prerequisite for survival, and claimed that the pressure of blood within the pericardial cavity contributed to the reduction and eventual cessation of haemorrhage from the cardiac wound. If these views are correct our patient was particularly fortunate to survive.

We are grateful to the following consultant physicians both for their permission to publish details of the patient and for their help and encouragement in the preparation of this report:Dr. G. M. Barrett, Royal Lancaster Infirmary, Dr. R. W. Emanuel, National Heart Hospital, and Dr. G. E. Royston, Barnet General Hospital.

\section{References}

Ballance, C. A. (1920). Bradshaw lecture on the surgery of the heart. Lancet, I, I, 73, and 134 .

Kearns, J. J. (1935). An unusual case of suicide. American fournal of Surgery, 28, 166.

Larrey, Baron D. J. (1829). Des plaies du péricarde et du coeur: IVme observation. In Clinique Chirurgicale, Vol. 2, p. 31 5. Gabon and J. B. Baillière, Paris.

FIG. I The knife still covered with congealed blood.

FIG. 2 The anterior chest wall: the 2 stab wounds are encircled.
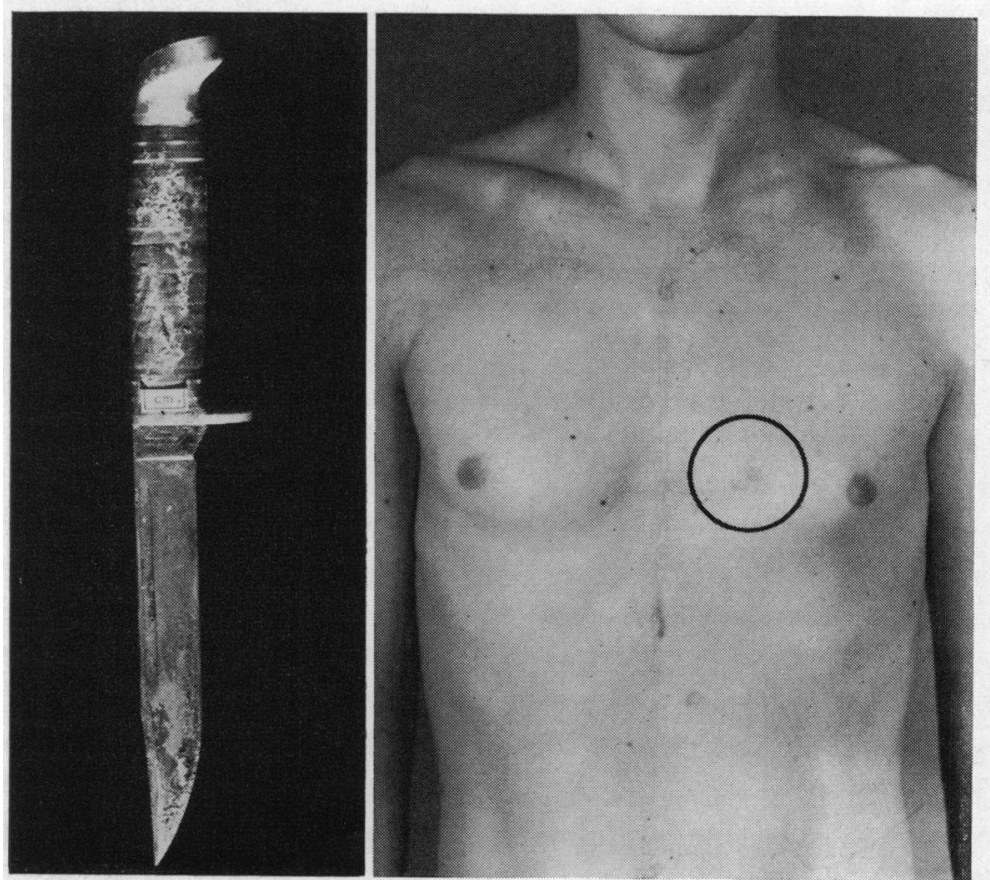
Maynard, A. De L., Cordice, J. W. V., Jr., and Naclerio, E. A. (1952). Penetrating wounds of the heart; a report of 81 cases. Surgery, Gynecology and Obstetrics, 94, 605.

Mühlig, Dr. (186I). Plaie pénétrante du coeur perforant la paroi du ventricule droit et la cloison interventriculaire. Gazette Médicale d'Orient, 4, 95.

Parmley, L. F., Mattingly, T. W., and Manion, W. C. (1958). Penetrating wounds of the heart and aorta. Circulation, 17, 953.

Piga, A. (1929). Un caso raro de suicidio. El Siglo Médico, 84, 421. 